NBER WORKING PAPER SERIES

THE AFTER TAX RATF OF RETURN AFFECTS PRIVATE SAVINGS

Laurence H. Summers

Working Paper No. 1351

NATIONAL BUREAU OF ECONOMIC RESEARCH 1050 Massachusetts Avenue

Cambridge, MA 02138

May 1984

This paper was prepared for the December 28-30, 1983 meeting of the American Economic Association. It draws very heavily on a longer paper. "Tax Policy, The Rate of Return, and Savings," which has been issued as NBER Working Paper 995. The research reported here is part of the NBER's research program in Taxation and project in Government Budget. Any opinions expressed are those of the author and not those of the National Bureau of Economic Research. 
NBER Working Paper \#1351

May 1984

\title{
The After Tax Rate of Return \\ Affects Private Savings
}

\begin{abstract}
$\underline{\text { ABSTRACT }}$
This paper reviews theoretical arguments and empirical evidence regarding the interest elasticity of savings. It concludes that there are strong theoretical reasons to expect an increase in after tax rates of return to increase private savings. Moreover, the empirical methods used in most previous studies are likely to produce underestimates of the interest elasticity of savings. New evidence based on direct estimation of utility function parameters suggests that savings are likely to be highly interest elastic. The paper concludes by noting that too little time has passed to evaluate the effects of the savings incentives contained in recent tax legislation.
\end{abstract}

Lawrence H. Summers Department of Economics Harvard University 617-495-2447 
The effects of the rate of return on the level of savings and the rate of capital formation are of central concern to both economists and policymakers. Although the welfare effects of tax reforms do not directly depend on their impact on savings, the effects of taxes on savings is crucial to considerations of tax incidence and equity and to the issue of long run growth. The impact of the rate of return on consumption and savings decisions also bears on questions regarding the appropriate government discount rate, the short run crowding out effects of fiscal policy, and the effects of public indebtedness on capital intensity.

The traditional view among economists is that changes in the rate of return are likely to have only a small effect on the savings rate. This consensus is supported by theoretical arguments pointing to the opposing income and substitution effects associated with changes in the rate of return. The ambiguous implications of theory are matched by empirical studies which yield conflicting estimates as to the size of the impact of changes in the rate of return. The polar empirical estimate is Michael Boskin's (1978) suggestion that the interest elasticity of savings is .4. This estimate is widely regarded as too high.

This paper re-examines the theoretical arguments and reviews new empirical evidence regarding the interest elasticity of savings. Both the theoretical analysis and the empirical work demonstrate the strong likelihood that increases in the real after-tax rate of return received by savers would lead to substantial increases in long run capital accumulation. While it is not possible to quantify the impact with any precision, it seems reasonable to believe that a shift towards expenditure taxation would lead to significant increases in the private savings rate. I argue that the failure of 
traditional empirical approaches to isolate significant rate of return effects is a consequence of their failure to distinguish between transitory and permanent changes in the rate of return, and of other specification errors.

The theoretical analysis emphasizes the importance of recognizing heterogeneity among savers in examining the effects of tax changes which raise the rate of return available to savers. It begins by demonstrating that even if all savings decisions are determined by rule of thumb, savings are likely to be elastic with respect to the rate of return, as long as the rules of thumb differ persistentiy across households. The effects of changes in the rate of return on savings are then considered in a realistic multi-period lifecycle framework. Within such a framework, the importance of recognizing future labor income in analyzing savings is stressed. It is shown that for a wide range of utility function parameters, the interest elasticity of savings is likely to be positive. Since recent research suggests the importance of bequests in determining aggregate capital formation, models of intergenerational transfers are also considered. It is shown that as long as any part of the economy is comprised of households with operative intergenerational transfer motives the long run impact is also likely to be substantial. While the sign of the response of savings to a change in the interest rate cannot be determined unambiguously from theoretical considerations, consideration of several models leads to a presumption in favor of a positive response.

Section I discusses theoretical approaches to the linkage between savings and the rate of return. Section II critiques the traditional consumption function approach to examining rate of return effects on savings behavior, and reviews estimates obtained using alternative new methodologies. Section III concludes the paper by discussing the implications of the results for current economic policy discussion. 


\section{Theoretical Considerations.}

In a closed economy, it is not possible to imagine how the rate of. return to savers could change without other relevant economic variables also changing. Thus, it is necessary to be clear about the nature of the shock causing the rate of return to change. Discussions of the "interest elasticity of savings" are apt to be misleading since the change in savings associated with any given change in the rate of return to savers will depend on what caused the rate of return to change. The analysis here focuses on the effects of tax policies which alter the rate of return available to savers. Any tax change will affect revenue collections and so must be associated with changes in either government spending, public borrowing or other tax collections. The analysis here is all based on a differential incidence approach, where it is assumed that spending and total revenue collections remain constant so that changes in capital income taxes are offset by adjustments to payroll or consumption taxes. All the discussion is, therefore, about compensated effects. An effort is made to maintain this distinction in drawing implications from the empirical work in the discussion below. 1 /

The discussion here focuses on the "partial equilibrium effects" of a change in the rate of return. It is assumed that factor prices are unaffected by changes in the savings rate. Thus the analysis addresses the supply of savings schedule rather than the reduced form relationship between tax changes and capital intensity. In the special cases of a small open economy or a production function with an infinite elasticity of substitution, the assumption of constant factor prices will be valid. Otherwise, it would be necessary to consider the aggregate production function in assessing the ultimate effect of a change in tax policy on private savings. 
$\underline{\text { Rule of Thumb Savings }}$

Economic theory needs to simplify reality enormously if anything tractable is to result. But it is important to acknowledge at the outset that no single analytic model can capture the complex motivations for any one individual's savings decisions let alone the savings decisions of the entire population. It turns out the existence of substantial diversity in savings behavior, creates a presumption in favor of a positive savings response to increases in the rate of return. $2 /$

Consider a population made up of "rule of thumb savers" each of whom saves regardless of the rate of return a fixed fraction of his total disposable income. The "rule of thumb" rate of saving varies across individuals; some are liquidity constrained and consume everything, others may have a quite high marginal propensity to save. Now imagine a reduction in the tax rate on capital income, financed by an equal revenue yield increase in labor income tax rate. Such a measure would, assuming some persistence in savings propensities, redistribute income from persons with low to persons with high savings propensities. As a consequence national savings would increase, even though no individual's savings incentive was affected. As time passes, the savings rate will rise further, as the share of total income going to persons with high savings propensities increases.

\section{$\underline{\text { Life Cycle Savings }}$}

Perhaps the dominant theoretical model used by economists in analyzing long run questions relating to savings behavior is the life-cycle hypothesis of Franco Modigliani. In an earlier paper, Summers (1981), I argued that realistic formulations of the life-cycle hypothesis implied a very substantial long run response of capital accumulation to tax measures that change after tax 
rates of return. The essential reason for the responsiveness of savings was the "human wealth" effect associated with changes in the after tax rate of return. Increases in the after tax rate of return reduce human wealth defined as the present value of individuals' labor income claims. This effect is absent in the two period textbook formulations with all income received in the first period.

The claims put forward in Summers (1981) about the high interest elasticity of savings have been challenged by Evans (1983) and Starrett (1982) who argue that they do not survive generalization of the model. Evans' principal point is that if one assumes a significantly negative time preference rate and a very low intertemporal elasticity of substitution, a relatively small interest elasticity of substitution will result. His rhetoric seems rather overblown given that the elasticity is positive in every case he considers, and greater than .4 in most cases. Moreover, empirical evidence casts doubt on the relevance of the parameter values underlying Evans' low elasticity cases. 3 / Starrett (1982) shows that lower elasticities of savings can be generated using non-homeothetic utility functions. However, both empirical evidence and theoretical considerations support the standard procedure of imposing homeotheticity. On balance, there remains reason to believe that life-cycle saving is very likely to respond positively to after tax rates of return, but the question is ultimately an empirical one.

\section{Bequest Savings}

Recent research [e.g., Kotlikoff and Summers (1981)] suggests that bequests may account for a large fraction of national capital formation. The papers by Evans (1983) and Starrett (1982) discussed above argue that taking account of bequests makes it very plausible that the interest elasticity 
of savings is negative. The critical issue is how bequests are modelled. In Summers (1982), I establish the following results. As long as any part of the population is saving for altruistic bequests, the long run partial equilibrium elasticity of savings with respect to the rate of return will be infinite. Illustrative calculations suggest that it is likely to be very high in the short run as well. Thus taking account of bequests increases the predicted elasticity of savings.

of course alternative formulations of the bequest process are possible, although it seems hard to entirely rule out altruism. My own favorite is outlined in Bernheim, Shleifer and Summers (1983). It has implications similar to the standard life cycle model. Seidman (1983) incorporates bequests into my (1981) model by assuming that they generate utility directly for donors and get results qualitatively similar to mine. Evans gets low or negative elasticities only by assuming counterfactually that bequests are typically passed over a span of two generations, and by employing an ad hoc treatment that allows for no substitutability between bequests and consumption in donors' utility functions. He presents no evidence to support either of these assumptions. The combination of the considerations discussed in this section suggest that the data should be approached with at least a mild presumption in favor of the hypothesis that savings respond positively to real after tax rates of return. There are certainly internally consistent theoretical models which lead to a different conclusion but their premises do not seem compelling. We now turn to the empirical evidence.

\section{Empirica1 Evidence}

A large number of authors including Wright (1970, 1979), Weber (1970, 
1975), Boskin (1978), Howrey and Hymans (1980), and Blinder (1981) have attempted to estimate the effects of changes in the rate of return on consumption and savings using Keynesian consumption functions. No consensus has emerged. Only Boskin obtains a statistically significant and substantial positive interest elasticity of savings. Howrey and Hymans (1980) show that his results are extremely sensitive to the choice of sample period, and to issues of data construction. I believe that there are fundamental conceptual problems which make it almost inconceivable that consumption function estimation can ever answer the questions of interest. Three difficulties seem paramount .

First, theory, particularly in the case of life cycle savers, suggests that the value of consumers' endowments is a function of the interest rate. Increases in the real after tax interest rate reduce the value of human wealth, and may affect marketable wealth as well. These effects are not captured in standard formulations. When they are taken account of using a full macroeconomic model as in Modigliani (1971), or a modified single equation consumption function as in Summers (1982), dramatic positive effects of increases in rates of return on savings result.

Second, the question of primary interest to persons concerned with tax policy is the response of savings to permanent changes in the real after tax rates of return. The experiments provided by history came in the form of largely transitory changes in after tax rates of return. Both theory and common sense suggest the response to temporary changes in rates of return should be much smaller than the response to permanent changes. This creates a strong presumption that simple extrapolation of the historical experience will lead to very substantial underestimates of the response of savings to 
permanent changes in the rate of return. This presumption is magnified by the very high noise-signal ratio in any attempted estimates of the real after tax rate of return over a long horizon.

Third, there are the standard set of difficulties associated with any Keynesian consumption function. Almost all the right hand side variables are probably endogenous. There is no satisfactory way of meeting the Lucas critique in modelling expected future labor income. No variables are included which address theoretically relevant issues such as the age structure of the population, or expected retirement ages. In an important recent study, Auerbach and Kotlikoff (1981) illustrate the behavior of an economy in which the life-cycle hypothesis holds exactly, and then fit standard consumption functions. The results indicate that parameter estimates are extremely sensitive to the choice of sample period, and that estimated parameters do not provided a useful guide to the effect of policy interventions. What then can be done? I have suggested the futility of standard consumption function estimation for answering questions relating to long run tax policies. Recent work by Grossman and Shiller (1981), Hensen and Singleton (1982) and many others suggests an alternative approach. $4 /$ In general, it is possible to estimate the parameters of the utility function driving consumers' behavior, even where it is impossible to estimate any kind of structural consumption function. Essentially identification comes from the requirement that consumers satisfy certain first order conditions for utility maximization. This can be done using data on individual consumers as in Runkle (1983) and Shapiro (1983) or, with aggregation assumptions, on aggregate data. Allowance can be made for the possibility that some consumers are liquidity constrained. Once utility functions have been directly estimated, simulation 
exercises of the sort performed in my 1981 paper can be used to estimate the effects of tax reforms. Of course much more complex analyses taking account. of individual diversity, and adding realistic information on wage earnings profiles should be possible.

At this point, the results of such elaborate simulation exercises cannot be predicted. However available evidence tends to suggest that savings are likely to be interest elastic. I find in the more reliable estimates in my 1982 paper, values of the intertemporal elasticity of substitution which cluster at the high end of the range Evans and I considered. Similar estimates are found using micro-data by Shapiro (1983) and by Hansen and Singleton (1982). Where investigators find low estimates of intertemporal elasticity of substitution, it is usually because of the difficulty in modelling ex-ante rates of return on corporate stock. It is also noteworthy that if proper allowance is made for trend growth in the economy, estimated time preference rates are positive, reinforcing the positive effects of rates of return on savings. Future research, particularly using micro-data, will help to refine these conclusions and will enhance considerably our understanding of savings behavior.

\section{Policy Implications}

The U.S. economy now appears to be plagued by large structural budget deficits which appear likely to continue for the remainder of the decade unless major policy actions are taken. Private savings rates as measured in the National Income and Product Accounts do not appear to have increased along with the budget deficits. Indeed, many observers have expressed surprise that given the tax measures enacted in 1981, and the subsequent run up in real interest rates, savings rates have not increased sharply. Some go as far 
as to call this a serious blow to supply side economics.

Several observations should help to put this discussion in perspective. Unless savings are extraordinarily elastic with respect to rates of return, reductions in taxes will reduce the total supply of savings. Reduced public savings will not be offset by increases in private savings. The hope of those who advocated savings incentives was that in the long run the revenue effects of these measures would be offset by reductions in spending or increases in other taxes. There is no serious case that permanent public dissavings to finance incentives is a viable strategy for raising national savings.

Does the stability of the private savings rate over the last several years constitute evidence against the view that savings respond positively to rate of return incentives? Probably the sample is too short to permit conclusive judgments. Many other things happened over the last several years. For example, if the accrued gains to households on common stock are treated as part of income, the private savings rate was close to 20 percent over the last 18 months. At the same time that wealth was rising rapidly, households were suffering through a severe temporary recession, tending to put further downward pressure on savings rates. A final factor working to make the private savings rate appear artificially low in recent years has been the erosion of inflation, which has led to unmeasured increases in real disposable income and savings.

These factors lead to the conclusion that the evidence is not in on the savings aspect of Reagan's economic experiment. One of the few virtues of the macro-economic turmoil we have suffered in recent years is that it has increased the power of our econometric experiments by raising the variance of most exogenous variables. Within a few years we should have made considerable progress towards resolving the uncertainties discussed in this paper. 


\section{Footnotes}

1/ As noted below, "compensated savings effects" are not well defined because savings are not a commodity. As illustrated in Summers (1981), the effect of a tax change will depend on the timing of compensation.

2f The argument here is developed rigorously in Seidman (1983) and Summers (1982).

3/ Evans also repeats without attribution the analysis in my 1978 working paper suggesting that the short run elasticity with respect to a permanent change in the rate of return will exceed the long run elasticity. Without explanation, he calls this implausible and claims that it undercuts the long run analysis. Evans also speaks of a "general equilibrium" elasticity which is less than the partial equilibrium elasticity I compute. Figure 1 of my original paper and the accompanying discussion should have made this point clear.

4/ A survey of this burgeoning literature may be found in Mankiw, Rotemberg, and Summers (1984). The method of estimation described here is frequently labelled the Euler equation approach. 


\section{References}

Auerbach, A. J. and L. Kotlikoff, "An Examination of Empirical Tests of Social Security and Savings," National Bureau for Economic Research Working Paper 730, August 1981.

Bernheim, B. D., A. Shleifer and L. H. Summers, "A Model of Manipulative Bequests," mimeo, August 1983.

Blinder, A. S., "Temporary Tax Cuts and Consumer Spending," Journal of Political Economy, Vo1. 89, February 1981, pp. 26-53.

Boskin, M. J., "Taxation, Saving, and the Rate of Interest," Journal of Political Economy, Vol. 86, April 1978, pt. 2, pp. S3-27.

Evans, O. J., "Tax Policy, the Interest Elasticity of Saving and Capital Accumulation," American Economic Review, June 1983, pp. 398-410.

Hansen, L. G. and K. Singleton, "Stochastic Consumption, Risk Aversion, and the Temporal Behavior of Asset Returns," Journal of Political Economy, Vol. 91, Apri1 1983, pp. 249-265.

Howrey, E. P. and S. Hymans, "The Measurement and Determination of Loanable Funds Saving," Brookings Papers on Economic Activity, 1978, 3, pp. 655-685.

Kotlikoff, L. and L. H. Summers, "The Importance of Intergenerational Transfers in Aggregate Capital Accumulation," Journal of Political Economy, Vol. 89, August 1981, pp. 706-732.

Lucas, R. E., Jr., "Econometric Policy Evaluation: A Critique," in Karl Brunner and Allen H. Metzler, eds., The Phillips Curve and Labor Markets, CarnegieRochester Conference Series on Public Policy, Vol. 1, Amsterdam, North Holland, 1976, pp. 19-46.

Mankiw, G., J. Rotemberg, and L. H. Summers, "Intertemporal Substitution in Macroeconomics," Quarterly Journal of Economics, forthcoming 1984.

Runkle, D., "Testing for Liquidity Constraints using Euler Equation Methods," mimeo, Brown University, 1983.

Seidman, L. S., "Taxes in a Life Cycle Growth Model with Bequests and Inheritances," American Economic Review, June 1983, pp. 437-442.

Seidman, L. S., and S. B. Mancur, "Taxes and Capital Intensity in a Two Class Disposable Income Growth Model," Journal of Public Economics, 1982, pp. 243-259.

Shapiro, M., "The Permanent Income Hypothesis and the Real Interest Rate: Some Evidence from Panel Data," Economic Letters, Vol. 14, No. 1, 1984, pp. 93-100. 
Starrett, D., "The Interest Elasticity of Savings," mimeo, Stanford University, 1982 .

Summers, L. H., "Capital Taxation and Accumulation in a Life Cycle Growth Model," American Economic Review, Vol. 71, September 1981, pp. 533-544.

Summers, L. H., "Tax Policy, the Rate of Return and Savings," National Bureau for Economic Research Working Paper 995, September 1982.

Weber, W. E., "The Effect of Interest Rates on Aggregate Consumption," American Economic Review, Vo1. 60, September 1979, pp. 591-600.

Weber, W. E., "Interest Rates, Inflation and Consumer Expenditures," American Economic Review, Vol. 65, December 1975, pp. 843-858.

Wright, C., "Savings and the Rate of Interest," in Harberger and Bailey, eds., The Taxation of Income from Capital, 1969, Washington: The Brookings Institution, pp. 275-300. 